\title{
Analysis of sugar mill effluent and its influence on germination and growth of African marigold (Tagetes erecta $\mathrm{L}$.)
}

\author{
Thanapal Vaithiyanathan ${ }^{1} \cdot$ Perumal Sundaramoorthy $^{2}$
}

Received: 11 December 2015/Accepted: 19 October 2017/Published online: 31 October 2017

(c) The Author(s) 2017. This article is an open access publication

\begin{abstract}
Sugar industry is a very important agro-based industry in India and it discharges large amount of effluent into water bodies to create high pollution in water bodies which affects the plants and other living organisms. In the present investigation, the physico-chemical analyses of $\mathrm{N}$. P. K. R. Ramaswamy co-operative sugar mill effluent was determined and impact of different concentrations (control, $10,25,50,75$ and 100\%) of sugar mill effluent on seed germination behavior of African marigold (Tagetes erecta L.) was studied. The morphological parameters such as germination percentage, shoot length, root length, fresh weight and dry weight of seedlings, seed vigour index, tolerance index and percentage of phytotoxicity were calculated. The results recorded for the analyses of sugar mill effluent indicated their some parameters such as $\mathrm{P}^{\mathrm{H}}, \mathrm{EC}$, acidity, TDS, TS, BOD, COD, sulphate, magnesium, nitrogen, zinc, iron, copper, lead, manganese and oil and grease exceeded the permissible limit compared to Tamil Nadu Pollution Control Board (TNPCB) and then germination and growth parameters increased in lower (10\%) concentration of sugar mill effluent and this morphological parameters gradually decreased with increasing effluent concentration. The lower (10\%) concentration of sugar mill effluent may be used for irrigation purposes.
\end{abstract}

Thanapal Vaithiyanathan

vaithiyanathant@yahoo.in

1 PG Research Department of Botany, Vivekanandha College of Arts and Sciences for Women, Elayampalayam, Tiruchengode, Namakkal, Tamil Nadu 637 205, India

2 Department of Botany, Annamalai University, Annamalai Nagar, Chidambaram, Tamil Nadu 608 002, India
Keywords African marigold - Germination - Physicochemical analysis - Phytotoxicity and sugar mill effluent

$\begin{array}{ll}\text { Abbreviations } \\ \text { APHA } & \text { American Public Health Association } \\ \text { BOD } & \text { Biological oxygen demand } \\ \text { COD } & \text { Chemical oxygen demand } \\ \text { DAS } & \text { Days after sowing } \\ \text { DO } & \text { Dissolved oxygen } \\ \text { EC } & \text { Electrical conductivity } \\ \text { G \% } & \text { Germination percentage } \\ \mathrm{HgCl} & 2 \\ \text { mM/hrs } & \text { Mercury chloride } \\ \text { ppm } & \text { Partlimole per hours } \\ \text { SS } & \text { Suspended million } \\ \text { TDS } & \text { Total dissolved solids } \\ \text { TNPCB } & \text { Tamil Nadu Pollution Control Board } \\ \text { TS } & \text { Total solids }\end{array}$

\section{Introduction}

Environmental pollution is one of the primary issues of the globe. Industrialization is the main cause for environmental pollution. It is very essential for developing country on the other side it discharge hazardous materials into environment. Water is mainly affected by industries due to huge amount of effluent released into water bodies. It changes the physico-chemical properties of water and harmfully affected plants and other living organisms. In fact, industrial waste and other different human activity waste have emerged as one of the main reasons of pollution of water bodies. Human-induced activities can alter the natural 
source of contaminants and also initiate pollution load in the receiving water bodies (Whittemore et al. 1989). The corrosion of groundwater quality affects its usage for domestic, agriculture and industrial activities (Brindha and Elango 2012; Selvakumar et al. 2014). Approximately, one-third of death and $80 \%$ of diseases in the developing nations are caused by the drinking of contaminated water (WHO 2004). Industries are categorized into three types such as Red (high polluting industry), Orange (polluting industry) and Green (moderately or non-polluting industry) based on produced hazardous wastes into environment by Ministry of Environment and Forests, India. Industries are huge amount of waste water release into nearby water bodies and it affects the nature of water (Sundaramoorthy et al. 2006). Sugar mill is coming under red category and is one of the vital agro-based industries in India and is notably answerable for creating substantial impact on rural economic system but it released large amount of effluents at some stages in sugar manufacturing. It contained excessive degree of organic pollution and affected environment (Saranraj and Stella 2012). The enormous quantity of effluent release into water bodies with partially or without any treatment from sugar industry (Borole and Patil 2004). Nowadays, the discharged effluent is one of the main problems to be faced in the future with increased disagreeable effects (Moazzam et al. 2012). It has also been reported that high amount of pollutants present in the sugar mill effluent. It changed the normal water condition and caused adverse effects on living organisms (Ayyasamy et al. 2008).

In India, most of the people depend upon the agriculture. Agriculture is major work in India. Total agricultural land (Hectare and \% of total agricultural land area) was measured at $17,97,99,000$ and $60.47 \%$ in 2011 in India according to the World Bank. Water is vital resources of agriculture and all living organisms. Huge amount of water used for irrigation but nowadays increased water demands because of scarcity of water. So, the farmers used waste water for irrigation purposes which is alternative sources of scarcity of water. Sugar mill produced large amount of wastewater during sugar production and discharged into nearby water bodies (Ezhilvannan et al. 2011). Sugar mill effluent had more quantity of BOD, COD, dissolved solids and suspended solids. Further to that, the excessive amount of chlorides, sulfates, nitrates, calcium, magnesium and some traceable amount of heavy metals inclusive of zinc, copper and lead were presented in this effluent that effluent used for the irrigation of surrounding farmers. The effluent harm full affects the plant growth as well as soil fertility while used for irrigation (Kumar and Chopra 2010; Jagannathan et al. 2014). Soil was highly contaminated when untreated effluent was used for irrigation which contained high organic compounds and heavy metals (Salem et al. 2000; Sebastiani et al. 2004; Singh and Bhati 2005). This effluent contains high quantity of nutrients that have the potential for use in agriculture. So, the effluent reduces the fertilizer and scarcity of water and it includes wealthy in numerous plant nutrients (Kumar and Chopra 2012).

Food crops are not advisable for cultivation under effluent irrigation because it affects the food crops and deposited heavy metals in the plant tissue and also affected the consumer. But the ornamental plants are cultivated under effluent irrigation. In India, the cultivation of ornamental plants and flowers for more uses, especially the flowers are exported many countries (Razzaq owayez Idan et al. 2014). African Marigold (Tagetes erecta L.) belongs to family Asteraceae is commonly cultivated in throughout the India and marigold flowers are used in many festivals such as religious and social functions in different forms (Singh et al. 2001). African marigold flowers are very attractive colour in nature. On occasion, the complete plants can be used for decorations (Desai 1967). High amount of carotinoid and xanthophyll pigments present in marigold and particularly $80-90 \%$ of lutien present in the marigold. So, it is cultivated commercially in various parts of India (Alam 1968). Seed germination is a critical stage that ensures reproduction and controls the dynamics of plant populations. So, it is an important test of probable crop productivity (Radosevich et al. 1997). The present study deals with the analyses of sugar mill effluent and its effect on seed germination and growth of Tagetes erecta (L.).

\section{Materials and methods}

\section{Effluent collection}

The effluent samples were collected in plastic containers from the out let of the N. P. K. R. Ramaswamy Co-operative sugar mill in Thalainayar, Mayiladuthurai Taluk, Nagapattinam District, Tamil Nadu, India. This sugar industry lies in latitude/longitude $11.10^{\prime} \mathrm{N} / 79.65^{\prime} \mathrm{E}$. The effluent were brought to the Ecology Laboratory, Department of Botany and stored in refrigerator at $4{ }^{\circ} \mathrm{C}$ for further use.

\section{Seed collection}

Tagetes erecta L. seeds were procured from Tamil Nadu Agricultural University (TNAU), Coimbatore, Tamil Nadu, India.

\section{Analysis of sugar mill effluent}

The collected sugar mill effluent sample was analysed for their various physico-chemical properties in Ecology 
Laboratory, Department of Botany, Annamalai University as per the routine Standard methods mentioned in APHA (2005).

\section{Preparation of different concentrations of effluent}

The collected effluent sample from the outlet of sugar mill industry was treated as 100 per cent raw effluent. Different concentrations $(10,25,50,75$ and $100 \%)$ of sugar mill effluent were prepared freshly using distilled water whenever necessary (Lakshmi and Sundaramoorthy 2000). They were used for germination studies.

\section{Control: Distilled water}

10\%: $\quad 10 \mathrm{ml}$ effluent $+90 \mathrm{ml}$ water

25\%: $\quad 25 \mathrm{ml}$ effluent $+75 \mathrm{ml}$ water

50\%: $\quad 50 \mathrm{ml}$ effluent $+50 \mathrm{ml}$ water

75\%: $\quad 75 \mathrm{ml}$ effluent $+25 \mathrm{ml}$ water

100\%: Raw effluent

\section{Germination studies}

The healthy and uniform sized African marigold seeds were selected and surface sterilized with $0.1 \% \mathrm{HgCl}_{2}$ for 2 min and then thoroughly washed with tap water. Fifty seeds were placed equidistantly in plastic cups filled with $100 \mathrm{~g}$ sterilized soil [clay + sand (1:1)]. The seeds were irrigated with equal quantity of different concentrations of effluent and the seeds irrigated with distilled water were treated as control. Three replicates were maintained for each treatment including control. The germination percentage, shoot length, root length, seedling fresh weight and seedling dry weight (Milner and Hughes 1968; Sundaramoorthy et al. 2006; Sajani and Muthukkaruppan 2011) were taken and recorded on the 15th day seedlings. The values of seed vigour index, Tolerance index and percentage of phytotoxicity were also calculated.

\section{Germination percentage}

The number of seeds germinated in each concentration was counted on the 15th day and the germination percentage was calculated using the following formula.

Germination percentage $=\frac{\text { Number of seeds germinated }}{\text { Total numbers of seeds sown }}$

\section{Shoot and root length $(\mathrm{cm} / \mathrm{seedling})$}

Five seedlings were taken from each treatment and their shoot length and root length were measured by using a $\mathrm{cm}$ scale and these values were recorded.

\section{Fresh weight (g/seedling)}

Five seedlings were collected from each treatment and their fresh weights were measured with the help of an electrical single pan balance.

\section{Dry weight $(\mathrm{mg} /$ seedling $)$}

The same seedlings used for fresh weight were kept in hot air oven at $80{ }^{\circ} \mathrm{C}$ for $24 \mathrm{~h}$. Then, the seedlings were taken from the oven and kept in desiccators for some time. Their dry weights were taken using an electrical single pan balance.

\section{Vigour index}

Vigour index of the seedlings was calculated using the formula proposed by Abdul-Baki and Anderson (1973).

$$
\begin{aligned}
\text { Vigour index }= & \text { Germination percentage } \\
& \times \text { Length of seedling }
\end{aligned}
$$

\section{Tolerance index}

Tolerance index of the seedling was calculated using formula proposed by Turner and Marshal (1972).

Tolerance index

$$
=\frac{\text { Mean length of longest root in treatment }}{\text { Mean length of longest root in control }} \times 100
$$

\section{Percentage of phytotoxicity}

The percentage of phytotoxicity of effluent was calculated using the formula proposed by Chou et al. (1978).

$$
\begin{aligned}
& \text { Percentage of phytotoxicity } \\
& =\frac{\text { Radicle length of control-Radicle length of test }}{\text { Radicle length of control }} \times 100
\end{aligned}
$$

\section{Statistical analysis}

The experiment was repeated three times and data recorded each time were assembled for statistical analysis to determine the significance of variance $(P<0.05)$. For comparison of treatment means, standard errors were computed using SPSS (16.0) and Microsoft Excel programme.

\section{Results and discussion}

Physico chemical analyses of sugar mill effluent are given in Table 1. The evaluation of sugar mill effluent confirmed that it is acidic in nature and dull white in colour with decaying molasses smell. Colour is vital role of an aquatic 
ecosystem and it affects photosynthesis. Colouration reduced the some other parameters such as temperature DO and BOD, etc., and it also reduced to the decomposition of substances by microbes (Ingaramo et al. 2009; Buvaneswari et al. 2013; Saurabh and Shailja 2014). Decomposition of organic matter under anaerobic condition produced various sulphides, particularly ferrous sulphide which is caused for colour of the effluent. This is the most common gas and it simply soluble in water, colourless and inflammable, however, highly toxic. Some other gases, such as carbon dioxide, nitrogen, etc., from decomposition of organic compounds are responsible for odour of effluent. This is in conformity with the earlier finding of Vijayaragavan et al. (2011) and Rathore et al. (2000). In the present investigation, the $\mathrm{pH}$ value of the sugar factory effluents was 4.04 , which is acidic in nature. $\mathrm{pH}$ is very important factor for ecosystems that serve as an index for pollution. It

Table 1 Physico—chemical properties of sugar mill effluent

\begin{tabular}{|c|c|c|c|}
\hline S. no. & Properties & Raw effluent & $\begin{array}{l}\text { Tolerance limits } \\
\text { for agricultural } \\
\text { irrigation suggested } \\
\text { by TNPCB }(2009)\end{array}$ \\
\hline 1 & Colour & Dull white & Colourless \\
\hline 2 & Odour & $\begin{array}{l}\text { Decaying } \\
\text { molasses smell }\end{array}$ & - \\
\hline 3 & $\mathrm{pH}$ & 4.04 & $5.5-9.0$ \\
\hline 4 & $\begin{array}{l}\text { Electrical } \\
\text { conductivity (EC) }\end{array}$ & $4745 \mathrm{Mm} / \mathrm{h}$ & - \\
\hline 5 & Temperature $\left({ }^{\circ} \mathrm{C}\right)$ & 36.0 & 40.0 \\
\hline 6 & Acidity & 1350.0 & - \\
\hline 7 & Suspended solids & 180.0 & 200 \\
\hline 8 & Total dissolved solids & 3725.0 & 200 \\
\hline 9 & Total solids & 3905.0 & 2100 \\
\hline 10 & BOD & 3480.0 & 30 \\
\hline 11 & COD & 7880.0 & 250 \\
\hline 12 & Chloride & 314.0 & 600 \\
\hline 13 & Sulphate & 290.88 & 12 \\
\hline 14 & Magnesium & 286.0 & 100 \\
\hline 15 & Phosphorous & 7.2 & 10 \\
\hline 16 & Nitrogen & 1250 & 600 \\
\hline 17 & Fluoride & 1.88 & 1.0 \\
\hline 18 & Silica & 99.0 & - \\
\hline 19 & Calcium & 124.8 & 200 \\
\hline 20 & Zinc & 0.89 & 0.01 \\
\hline 21 & Iron & 16.00 & 1.00 \\
\hline 22 & Copper & 0.420 & 0.01 \\
\hline 23 & Lead & 0.52 & 0.05 \\
\hline 24 & Manganese & 0.068 & 0.01 \\
\hline 25 & Oil and grease & 19 & 10 \\
\hline
\end{tabular}

All parameters except colour, odour, $\mathrm{pH}, \mathrm{EC}$ and temperature are expressed in $\mathrm{mg} / \mathrm{l}$ is an indicator for the sustainability for the aquatic organisms. The normal $\mathrm{pH}$ is changed in the ecosystem which can affect living organisms. Various ions are present in the effluent and it directly related with $\mathrm{pH}$ of the effluent. The reaction among effluent flowing from open drainage system with the soil has direct relevance to $\mathrm{pH}$ of the effluent. The $\mathrm{pH}$ was acidic in nature because of the use of phosphoric acid and sulphuric acid during the clarification of sugarcane juice (Ayyasamy 2008). The sugar mill effluent contain high level of EC ( $4745 \mathrm{Mm} / \mathrm{h})$ which has a harmful affect to living organisms of the ecosystem. The temperature plays a major role in aquatic environment which is very high in sugar mill effluent $\left(36{ }^{\circ} \mathrm{C}\right)$ that has a lethal effect on the diversity of the aquatic environment. Normally, the organisms present in aquatic conditions rapidly grow at a temperature in the range of $20-27{ }^{\circ} \mathrm{C}$ (Ezhilvannan et al. 2011). The increased temperature may accelerate the rate of chemical reaction and chemical changes in the aquatic condition (Shiva Kumar and Srikantaswamy 2015). In agriculture irrigation has agreeable limits of temperature are $40{ }^{\circ} \mathrm{C}$. So, this sugar mill effluent has suitable temperature for irrigation.

It contained considerable amounts of SS $(180 \mathrm{mg} / \mathrm{l})$, chloride $(314 \mathrm{mg} / \mathrm{l})$, fluoride $(1.88 \mathrm{mg} / \mathrm{l})$, calcium $(124.8 \mathrm{mg} / \mathrm{l})$. Suspended particles are present in the water bodies which affect the light intensity of aquatic and it impact the turbidity and transparency of water bodies. The TDS and TS of sugar mill effluent were 3725 and $3905 \mathrm{mg} /$ 1. The findings were also in accordance to Borole and Patil (2004, Vinod and Chopra (2014a, b). Dissolved solids were in the form of colloidal substances which dissolved in effluent. The rate of dissolved colliding particles is referred to collision and the $\mathrm{pH}$ affected dissolved rate of collision in the effluent. Dissolved and non-dissolved substances called as total solids and it composed of carbonates bicarbonates, chlorides, sulphates, nitrates, $\mathrm{Ca}, \mathrm{Mg}, \mathrm{Mn}$, organic matter, silts and other particles which caused pollution of water bodies. It affects the intensity of light and living organisms (Poddar and Sahu 2015). BOD is an important parameter that indicates the magnitude of water pollution, by the oxidizable organic matter and the oxygen used to oxidize inorganic material such sulphides and ferrous ions. Present investigation showed that the effluent has high value of BOD (3480 mg/l) and COD (7880 mg/l). The chemical kinetic factor like temperature, pressure can affect the BOD reaction. BOD indicates of water pollution caused by oxidation of organic substances. It is one of the valuable parameter of the water quality. It is clear from the data that COD of effluent exceed the TNPCB limit. The high COD value is because of the presence of excessive amount of organic wastes. Saranraj and Stella (2012) analysed various parameters of sugar mill effluent and they have recorded the high COD value. The COD test 
determines the required amount of oxygen for oxidation of organic substances by chemical oxidant. The strong oxidizing agents should be oxidized completely all organic substances except some other substances of effluent in acidic condition. The BOD and COD tests are used in indication of toxic conditions and the presence of biologically resistance substances in the sugar mill effluent (Malik et al. 2014; Poddar and Sahu 2015). High amount of magnesium (286 mg/l), sulphate (290.88 mg/l), nitrogen $(1250 \mathrm{mg} / \mathrm{l})$, oil and grease $(19 \mathrm{mg} / \mathrm{l})$ and the toxic heavy metals such as zinc $(0.89 \mathrm{mg} / \mathrm{l})$, iron $(16 \mathrm{mg} / \mathrm{l})$, copper $(0.420 \mathrm{mg} / \mathrm{l})$, lead $(0.52 \mathrm{mg} / \mathrm{l})$ and manganese $(0.068 \mathrm{mg} / \mathrm{l})$ were recorded in the collected sugar mill effluent sample. Besides the metals, oil and grease were used in sugar mill for various processes. It influenced the temperature, $\mathrm{pH}$, BOD, COD, DS and TS of the effluent. It affected all living organisms of aquatic and terrestrial ecosystems. Similar findings were recorded and reported by Rathore et al. (2000), Lakshmi and Sundaramoorthy (2000), Borole and Patil (2004).

Seed germination and seedling growth are vital for continuation of plant life and they are extremely vulnerable to environmental stress. Since germination is the first physiological process, several growth parameters such as percentage of germination and ultimately growth and yield of the crops are taken as criteria to assess the degree of pollution (Mishra and Pandey 2002). In the present investigation, the effects of different concentrations of sugar mill effluent on seed germination of African marigold Tagetes erecta (L.) were reported. The highest values of seed germination percentage (99.66) were recorded at $10 \%$ of sugar mill effluent concentration and the lowest values of germination percentage (46.34) were recorded at $100 \%$ of sugar mill effluent concentration (Fig. 1). The increase in germination percentage over control at lower concentrations $(10 \%)$ indicates the stimulation of physiologically inactive seeds of the lot by the effluent treatment as reported by Vinod (2014), Vaithiyanathan et al. (2014) and Suresh et al. (2014). The favourable amount of nutrients may be presented in lower concentration of sugar mill effluent. It created good environmental condition for seed germination then the seed of the nutrient present in the effluent. The lower concentration of effluent had many nutrients such as nitrogen, phosphorous, etc. which might have promoted the plant growth as suggested by Augusthy and Annsherin (2001). At the same time, the higher concentrations of sugar mill effluent inhibited the germination of African marigold. Large amount of organic and inorganic substances presented in higher concentration of sugar mill effluent which adversely affected the seed germination because of the higher salt content which caused change of osmotic pressure outside of the seed. It decreased water absorption of the seed and then inhibited the seed germination (Adriano et al. 1973).

The highest shoot length $(29.10 \mathrm{~cm} /$ seedling $)$, root length $(6.80 \mathrm{~cm} / \mathrm{seedling})$, fresh weight $(3.59 \mathrm{~g} / \mathrm{seedling})$ and dry weight $(0.420 \mathrm{mg} / \mathrm{seedling})$ were observed in lower concentration (10\%) of sugar mill effluent and the lowest shoot length $(9.43 \mathrm{~cm} / \mathrm{seedling})$, root length $(1.83 \mathrm{~cm} / \mathrm{seedling})$, fresh weight $(0.760 \mathrm{mg} / \mathrm{seedling})$ and dry weight $(0.074 \mathrm{mg} / \mathrm{seedling})$ were observed in higher concentration (100\%) of sugar mill effluent (Figs. 2 and 3 ). The highest vigour index (3578.15) and tolerance index (1.27) of seedlings were observed in $10 \%$ of effluent treated seedling and lowest vigour index (521.79) and tolerance index (0.340) were observed in $100 \%$ of effluent (Figs. 4 and 5). Percentage of phytotoxicity level was high $(0.65 \%)$ at $100 \%$ of effluent treated seedling (Fig. 6). Seedling growth and development are essential processed of life and propagation of plant species. They continuously depend on the external environment. Presence of various pollutants in lower concentrations of sugar mill effluent (at $10 \%$ ) increased the growth and development. These observations are in conformity with Lakshmi and Sundaramoorthy (2000), Saxena and Madan (2012), Ali et al. (2012) Malik et al. (2014). Higher concentrations of sugar mill effluent inhibited the root and shoot length of seedlings. It contained large amount of DS and SS which interfered and decreased the absorption of some other nutrients. The interference of heavy metals decreased the root and shoot length of the plant might be due to the affect of physiological processes of plant and it also involved in inhibition of enzyme activities, affected the nutrition, water imbalance and alternation of hormonal status changed the membrane permeability (Sharma and Dubey 2005). The fresh and dry weight of seedlings increased at $10 \%$ of sugar mill effluent concentration while decreased at higher concentration of sugar mill effluent. Some amount of nutrients and trace elements may be needed for seeds. These nutrients also presented in the effluent and it is important for plant growth. The lower concentration of sugar mill effluent contained required amount of nutrients presented which developed the growth of seedlings as well as fresh and dry weight of the seedlings. The required amount of various chemicals presented in the lower concentration of sugar mill effluent which promoted the plant growth (Lakshmi and Sundaramoorthy 2000; Siva Santhi and Suja pandian 2012). The higher concentrations of sugar mill effluent minimized the fresh weight and dry weight of seedlings. The decrease of seedlings weight may be due to the poor growth of seedlings under the higher concentrations of effluent irrigation. 
Fig. 1 Germination percentage of Tagetes erecta L. grown under different concentrations of sugar mill effluent

Fig. 2 Shoot length and root length of Tagetes erecta L. grown under different concentrations of sugar mill effluent

Fig. 3 Fresh weight and Dry weight of Tagetes erecta L. grown under different concentrations of sugar mill effluent
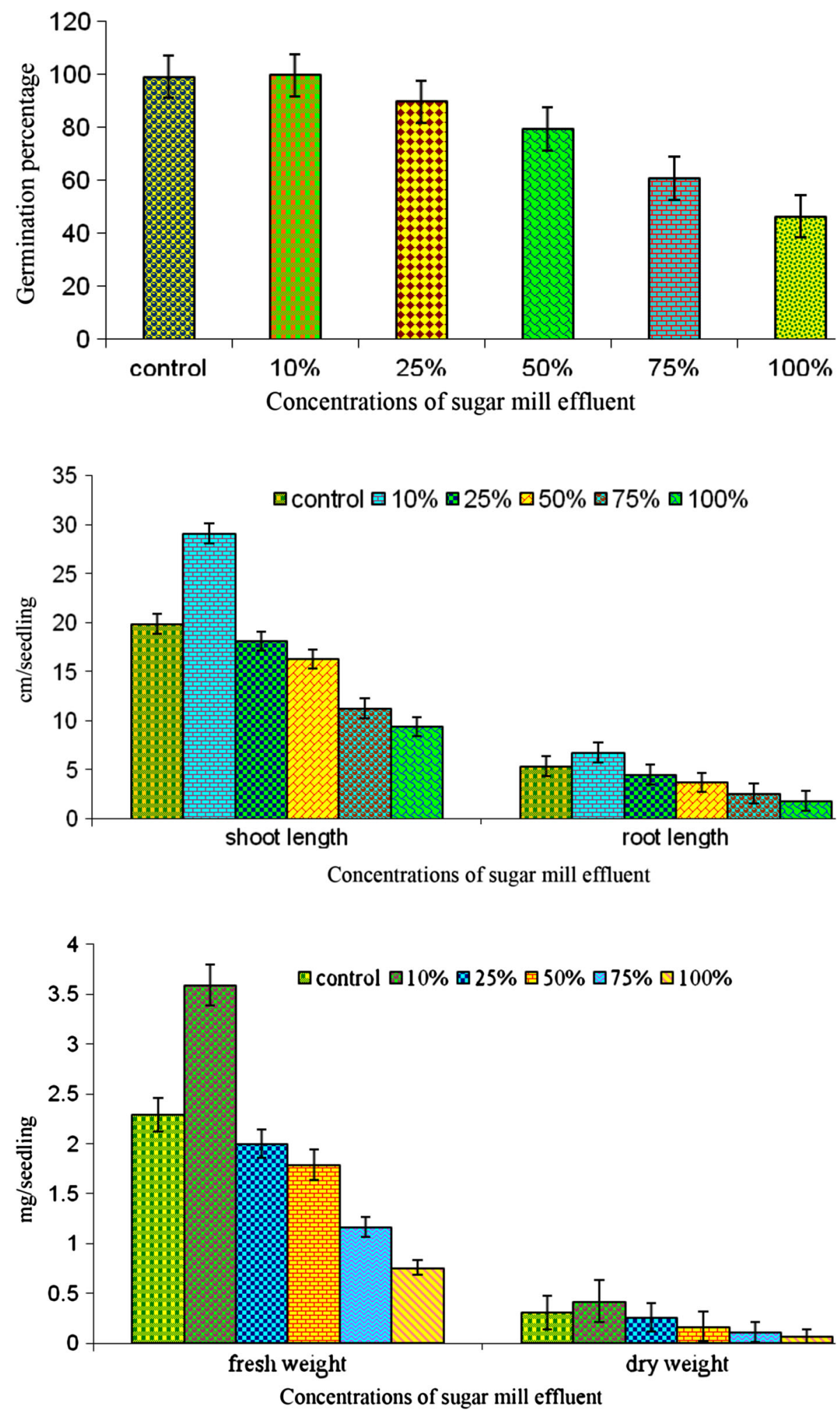
Fig. 4 Seed vigour index of Tagetes erecta L. grown under different concentrations of sugar mill effluent

Fig. 5 Tolerance index of Tagetes erecta L. grown under different concentrations of sugar mill effluent

Fig. 6 Percentage of phytotoxicity of Tagetes erecta L. grown under different concentrations of sugar mill effluent
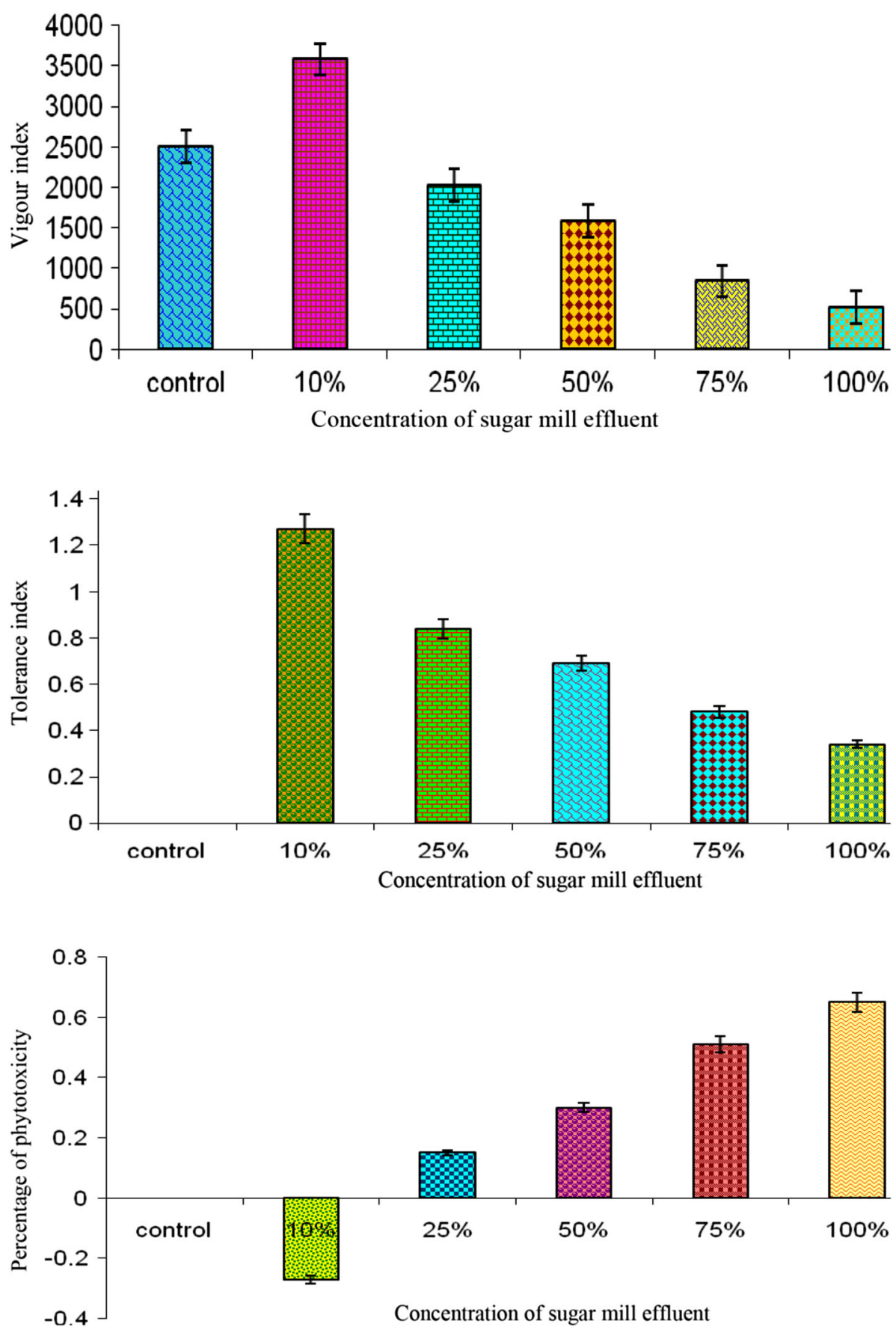

\section{Conclusion}

In the present study, results may that the sugar mill effluent had lot of organic and inorganic substances and it exceeded the tolerable limit for agricultural irrigation. The lower concentration $(10 \%)$ of sugar mill effluent promoted the seed germination and seedling growth of African marigold (Tagetes erecta L.) then other concentrations and control as well as germination and growth of African marigold gradually decreased with increased effluent concentrations.
It can also be concluded that not only toxic metals but higher nutrients can also be toxic and inhibited seed germination and seedling growth. Therefore, dilution of the sugar mill effluent is necessary to minimize the toxicity of sugar mill effluent and it has the potentiality as organic fertilizer. Besides, the lower concentration of effluent can be utilized for agricultural irrigation after suitable treatment with appropriate dilution.

Acknowledgements One of the authors Mr. T. Vaithiyanathan is thankful to UGC-SAP New Delhi India for providing UGC-BSR 
fellowship to carry out this research work. The authors are thankful to Professor and Head, Department of Botany, Annamalai University for providing laboratory facilities to carry out the research experiments.

Open Access This article is distributed under the terms of the Creative Commons Attribution 4.0 International License (http:// creativecommons.org/licenses/by/4.0/), which permits unrestricted use, distribution, and reproduction in any medium, provided you give appropriate credit to the original author(s) and the source, provide a link to the Creative Commons license, and indicate if changes were made.

\section{References}

Abdul-Baki AA, Anderson JO (1973) Vigour determination in soybean application of dairy manure on germination and emergence of some selected crops. J Environ Qual 3:396-399

Adriano DC, Chang AC, Pratt PE, Sharpness R (1973) Effect of application of dairy manure on germination and emergence of some selected crops. J Environ Qual 2:396-399

Alam AU, Cough IR, Creger CR (1968) Fatty acid composition of the xanthophylls esters of Tagetes erecta petals. Lipids 3:183

Ali HM, Khamis MH, Hassan FA (2012) Growth, chemical composition and soil properties of Tipuana speciosa (Benth.) Kuntze seedlings irrigated with sewage effluent. Appl Water Sci 2:101-108. https://doi.org/10.1007/s13201-012-0027-4

APHA (2005) Standard methods for the examination of water and wastewater, 21st edn. American Public Health Association, Washington

Augusthy PO, Annsherin M (2001) Effect of factory effluent on seed germination and seedling growth of Vigna radiatus (L.). J Environ Res 22(2):137-139

Ayyasamy PM, Yasodha R, Raja Kumar S, Lakshmanaperumalsamy P, Rahman PKSM, Lee S (2008) Impact of sugar factory effluent on the growth and biochemical characteristics of terrestrial and aquatic plants. Bull Environ Contam Toxicol 81:449-454

Borole DD, Patil PR (2004) Studies on physicochemical parameters and concentration of heavy metals in sugar industry. Pollut Res 23:83-89

Brindha K, Elango L (2012) Groundwater quality zonation in a shallow weathered rock aquifer using GIS. Geo-spatial Information Science 15(2):95-104. https://doi.org/10.1080/10095020. 2012.714655

Buvaneswari S, Damodarkumar S, Murugesan S (2013) Bioremediation studies on sugar-mill effluent by selected fungal species. Int J Curr Microbiol Appl Sci 2(1):50-58

Chou CH, Chiang YC, Khan CI (1978) Impact of water pollution on crop growth in Taiwan. Bot Bull Acadamic Sinica 19:107-124

Desai BL (1967) Flower description of Tagetes erecta. In: Seasonal flower, Indian Agricultural Research Institute, ICAR Publication, New Delhi, pp 53-56

Ezhilvannan D, Sharavanann PS, Vijayaragavan M (2011) Effect of sugar mill effluent on changes of growth and amino acid and protein contents of maize (Zea mays L.) plants. J Ecobiotechnol 3(7):26-29

Idan RO, Prasad VM, Saravanan S (2014) Effect of organic manures on flower yield of african marigold (Tagetes erecta L) CV. Pusa Narangi Gainda. Int J Agric Sci Res 4(1):39-50

Ingaramo A, Heluane H, Colombo M, Cesca M (2009) Water and waste water eco-efficiency indicators for the sugar cane industry. J Clean Prod 17:487-495
Jagannathan R, Venkatraman K, Vasuki R (2014) Bioremediation of sugar mill effluent by immobilized bacterial consortium. Int $\mathrm{J}$ Pharm Technol 6(3):7107-7114

Kumar V, Chopra AK (2010) Effect of industrial effluent irrigation on agronomical characteristics of two leguminous crops, Phaseolus vulgaris (L.) and Vigna radiata (L.). PhD Thesis, Department of Zoology and Environmental Science, Gurukula Kangri University, Haridwar (UK), India

Kumar V, Chopra AK (2012) Fertigation effect of distillery effluent on agronomical practices of Trigonella foenum-graecum L. (Fenugreek). Environ Monit Assess 184(3):1207-1219

Lakshmi S, Sundaramoorthy P (2000) Effect of sugar mill effluent on germination, seedling growth and biochemical changes in ragi (Elusine corocana Gaertn). Indian $\mathrm{J}$ Environ Ecoplan 3(3):501-506

Malik S, Bhati H, Kumar D, Kumar V (2014) Germination and seedling growth of Vigna radiata $\mathrm{L}$. under sugar mill effluent stress. Int J Pharm Res Bio Sci 3:54-59

Milner C, Hughes RE (1968) Methods for the measurement of primary production of grassland. IBP handbook no. 6. Blackwell, Oxford

Mishra V, Pandey SD (2002) Effect of distillery effluent and leachates of industrial sludge on the germination of blackgram (Cicer arietinum). Pollut Res 21(4):461-467

Moazzam AK, Shahid SS, Shahzad A, Hamda A (2012) Growth and yield responses of pearl millet (Pennisetum glaucum [L.] R.Br.) irrigated with treated effluent from waste stabilization ponds. Pak J Bot 44(3):905-910

Poddar PK, Sahu O (2015) Quality and management of wastewater in sugar industry. DOI, Appl Water Sci. https://doi.org/10.1007/ s13201-015-0264-4

Radosevich S, Holt J, Ghersa C (1997) Weed ecology implications for management. Wiley, New York

Rathore NP, Iqbal SA, Pawan KS (2000) Role or sugar industry effluent in agriculture. Indian J Appl Pure Biol 19:91-94

Sajani S, Muthukkaruppan SM (2011) Physico-chemical analysis of sugar mill effluent, contaminated soil and its effect on seed germination of paddy (Oryza sativa L.). Int J Pharm Biol Arch 2(5):1469-1472

Salem MM, El-Amir S, Abdel-Aziz SM, Kandil MF, Mansour SF (2000) Effect of irrigation with sewage water on some chemical characteristics of soils and plant. Egypt J Soil Sci 40:49-59

Saranraj P, Stella D (2012) Effect of bacterial isolates on reduction of physico-chemical characteristics in sugar mill effluent. Int $\mathbf{J}$ Pharm Biol Arch 3(5):1121-1128

Saurabh S, Shailja P (2014) Physico-chemical analysis of sugar mill effluent and their impact on changes of growth of wheat (Triticum aestivum) and maize (Zea mays L.). J Environ Sci Toxicol Food Tech 8(4):57-61

Saxena C, Madan S (2012) Growth response of Solanum melongena in three different adsorbents irrigated with sugar mill effluent. J Agric Bio Sci 7:325-329

Sebastiani L, Scebba F, Tognetti R (2004) Heavy metal accumulation and growth responses in poplar clones eridano (Populus deltoides 9 maximowiczii) and I-214 (P. 9 euramerilana) exposed to industrial waste. Environ Exp Bot 52:79-88

Selvakumar S, Chandrasekar N, Magesh NS, Kaliraj S (2014) Groundwater quality and its suitability for drinking and irrigational use in the Southern Tiruchirappalli district, Tamil Nadu, India. Appl Water Sci. https://doi.org/10.1007/s13201-014-0256-9

Sharma P, Dubey RS (2005) Lead toxicity in plants. Braz J Plant Physiol 17(1):35-52

Shiva Kumar D, Srikantaswamy S (2015) Evaluation of effluent quality of a sugar industry by using physico- chemical parameters. Int J Adv Res Eng Appl Sci 4(1):16-25 
Singh G, Bhati M (2005) Growth of Dalbergia sissoo in desert regions of western India using municipal effluent and the subsequent changes in soil and plant chemistry. Bioresour Technol 96:1019-1028

Singh HP, Schiva T, Zabeltetz C, Von Dadlani NK (2001) An integrated approach for small scale greenhouse floriculture in India. FAO, New Delhi, 203 p

Siva Santhi K, Suja pandian R (2012) Effect of sugar mill effluent on seed germination of peanut (Arachis hypogaea) and Green gram (Vigna radiate). Int J Pharm Chem Sci 1(2):804-806

Sundaramoorthy P, Chidambaram ALA, Sankar Ganesh K, Rajesh M (2006) Growth response on paddy (Oryza sativa L.) for sugar mill effluent irrigation. Pollut Res 25(4):749-752

Suresh B, Abraham K, Damodharam T (2014) Effect of sugar industry effluent on changes of growth and biochemical contents of Capsicum annuum L. Adv Appl Sci Res 5(5):305-309

Turner RG, Marshal C (1972) Accumulation of zinc by subcellular root of Agrostis tannis sibth in relation of zinc tolerance. New Phytol 71:671-676

Vaithiyanathan T, Soundari M, Sundaramoorthy P (2014) Response of black gram (Vigna mungo L.) to sugar mill effluent treatment. Int J Res Bot 4(1):15-18

Vijayaragavan M, Surshkumar J, Natarajan A, Vijayarengan P, Sharavanan S, Prabhahar C (2011) Soil irrigation effect of sugar mill effluent on changes of growth and biochemical content of Raphanus sativus L. Curr Bot 2:09-13

Vinod K (2014) Sugar mill effluent utilization in the cultivation of maize (Zea mays L.) in two seasons. J Waste Manag 12. https:// doi.org/10.1155/2014/408509

Vinod k, Chopra AK (2014a) Fertigational effects of sugar mill effluent on agronomical characteristics of high yield cultivar of sugarcane (Saccharum officinarum L.) in two seasons. Acta Adv Agric Sci 2(9):17-39

Vinod K, Chopra AK (2014b) Pearl millet (Pennisetum Glaucum L.) response after ferti-irrigation with sugar mill effluent in two seasons. Int J Recycl Org Waste Agric 3:67. https://doi.org/10. 1007/s40093-014-0067-x

Whittemore DO, Greggor KMM, Marotz GA (1989) Effects of variations in recharge on groundwater quality. J Hydrol 106:131-145

WHO (2004) Guidelines for drinking water quality, 3rd edn. World Health Organization, Geneva

\section{Publisher's Note}

Springer Nature remains neutral with regard to jurisdictional claims in published maps and institutional affiliations. 